\title{
Stratigraphical and palaeogeographical significance of the continental sedimentary transition across the Permian-Triassic boundary in Spain
}

\author{
José López-Gómez ${ }^{\mathrm{a}, *}$, Alfredo Arche ${ }^{\mathrm{a}}$, Mariano Marzo ${ }^{\mathrm{b}}$, Marc Durand ${ }^{\mathrm{c}}$ \\ a Instituto de Geología Económica (CSIC-UCM), Facultad de Geología, Universidad Complutense, C/Antonio Novais 2, 28040 Madrid, Spain \\ b Departament d'Estratigrafia, Paleontología i Geociències Marines, Facultat de Geología, Universitat de Barcelona, \\ Zona Universitaria de Pedralbes, 08028 Barcelona, Spain \\ ' Sciece de la Terre et UMR 7566 “G2R”, Université Henri Poincaré-Nancy I, BP n²39, F-545506 Vandoeuvre-lés-Nancy Cedex, France
}

\begin{abstract}
The Permian-Triassic transition, a time of phenomenal palaeoenvironmental and palaeogeographical change, represents the largest episode of mass extinctions known to palaeontologists. This episode is, however, very poorly understood, and a lack of sediments and palaeontological data, particularly in the continental record, is a feature common to every basin. Despite compelling information on the continental Permian-Triassic boundary (PTB) emerging from recent efforts evaluating vertebrate evolution, fungal events and isotope curves, results are still insufficient to make any valuable correlations among continental basins and are even less appropriate for relating sediments of continental to those of marine origin. The present report discusses and attempts to locate the PTB in the basins of Iberia and Balearic Islands through an analysis of the palaeontological and sedimentary record across the Permian-Triassic transition. The aim of the paper is to contribute to our present knowledge of the palaeogeographical and stratigraphical significance of the Permian and Triassic continental units of Western Europe.

The present-day Iberian Ranges, Catalonian Ranges and Balearic Islands hold the most complete Late Permian-Early Triassic sedimentary record in Iberia. This record consists of alluvial sediments, mainly of braided fluvial systems, corresponding to the "Saxonian" and Buntsandstein facies. All the units examined so far have been dated through palynological associations. The two "Saxonian" facies formations are of Thuringian age, although the lower one shows some palynological elements of Autunian affinities. The Buntsandstein units range from Thuringian to Anisian in age, there being no evidence up to now of the Scythian in Iberia. The exact position of the PTB in Iberia is up to now impossible to pinpoint with the precision of the marine series. Sedimentary characteristics and palynological data in the Iberian Ranges point that it lies at the sedimentary interval, 10 to $30 \mathrm{~m}$ thick, formed by the upper member of the La Hoz del Gallo Formation and the lowermost beds of the Cañizar Formation or its time equivalent the Prades and Eramprunyá units in the Catalonian Ranges and the Asá and B-1 in the Balearic Islands. We compare a normalized standard Late Permian-Middle Triassic column of the Iberian Ranges with standards from Western and Central Europe and the Southern Urals using recent Permian time scales. A palaeogeographic
\end{abstract}

\footnotetext{
* Corresponding author.

E-mail address: jlopez@geo.ucm.es (J. López-Gómez).
} 
essay map of the Permian Triassic transition is provided for the Iberian Plate. The plate was located in a northern subtropical position, $200400 \mathrm{~km}$ from the westernmost Tethys coast, as part of the Central Pangean Mountain Range comprised of the Appalachian Mauretanide Variscan orogenic belts of estimated altitudes $20004000 \mathrm{~m}$. Based on this palaeogeographic location, sedimentary characteristics and the main wind flows established for the Tethys, we can infer conditions of high precipitation dominated by monsoon and seasonal regimes with isolated semiarid areas for the lberian Plate during the transition.

Keywords: Late Permian; Triassic; Permian-Triassic boundary; Tberian Ranges; stratigraphy

\section{Introduction}

The end-Permian was for most palaeontologists the largest of five major Phanerozoic mass extinction episodes, and a time of considerable environmental change and lithosphere activity that triggered a chain of palaeogeographical changes affecting most of the planet. General recovery after the end of the Permian took most of the Triassic, although this recovery was only partial.

The exciting, enigmatic nature of the PermianTriassic boundary (PTB) has prompted a plethora of recent works that have attempted to explore new ideas concerning the factor or factors that may have provoked the changes observed across the boundary (Remne and Basu, 1991; Erwin, 1993; Hallam and Wignall, 1997; Isozaki, 1997; Kozur, 1989, 1998; Visscher et al., 1996; Wignall and Hallam, 1992; Yin and Tong, 1998; Twitchett, 2001; Twitchett et al., 2001; Looy et al., 2001; Benton and Twitchett, 2003; Racki, 2003, among others). There are no clear arguments supporting a sudden mass extinction accompanied by drastic palaeogeographical or atmospheric change, but rather the balance of opinions seems to favour a more gradual chain of events with drastic consequences. Moreover, continental and marine environments respond differently to change and although extinctions were more severe in the latter, in which $95 \%$ of all marine animal species became extinct, terrestrial ecosystems were also severely affected.

Investigations of the PTB are met with the main stumbling block of accurately estimating the age of continental late Permian-Early Triassic sediments. Descriptions of the sedimentary units of most of the world's sedimentary basins close to this transition indicate a lack of sediments, and still worse, in many cases the palaeontological record provides no clues on the magnitude of these voids or even if sediments initially existed or not. A few examples of basins well described through their continental sediments during this transition have indicated very complete successions. However, these successions hardly permit correlations to be made among separate basins or even between neighbouring basins. The coincidence between faunistic (reptiles) changes and drastic variations in $\delta^{13} \mathrm{C}$ excursion suggests that biological and palaeoenvironmental changes in the Karoo basin (South Africa) temporally coincided with others changes observed in the PTB of other regions and environments (MacLeod et al., 2000). In the same basin, a recent study established that mass extinctions of terrestrial fauna and flora around this boundary coincide with changes in the sinuosity of the river channel systems in the same sediments (Smith and Ward, 2001; Hancox et al., 2002). Many other reports on continental sediments have also indicated significant events or changes around the PTB, such as those related to the presence of fungi (Eshet et al., 1995; Visscher et al., 1996), the synchronous $\delta^{13} \mathrm{C}$ record (Morante, 1996), abrupt micro- and macrofloral modifications (Poor et al., 1997; Lozovsky, 1998), ecological landscape shifts and changes in palaeosol characteristics (Retallack and Krull, 1999; Krull and Retallack, 2000) or vertebrate extinctions (Rubidge, 1995; Smith and Ward, 2001), among others.

Despite problems in locating the PTB in continental sediments, the stratigraphical and palaeogeographical significance of this boundary requires additional information for understanding the Permian-Triassic transition across vast expanses of the world, including very different ancient latitudes. Permian-Triassic boundary in continental sediments were generally formed under different palaeogeographic and palaeotectonic conditions, so they show clear lithological 

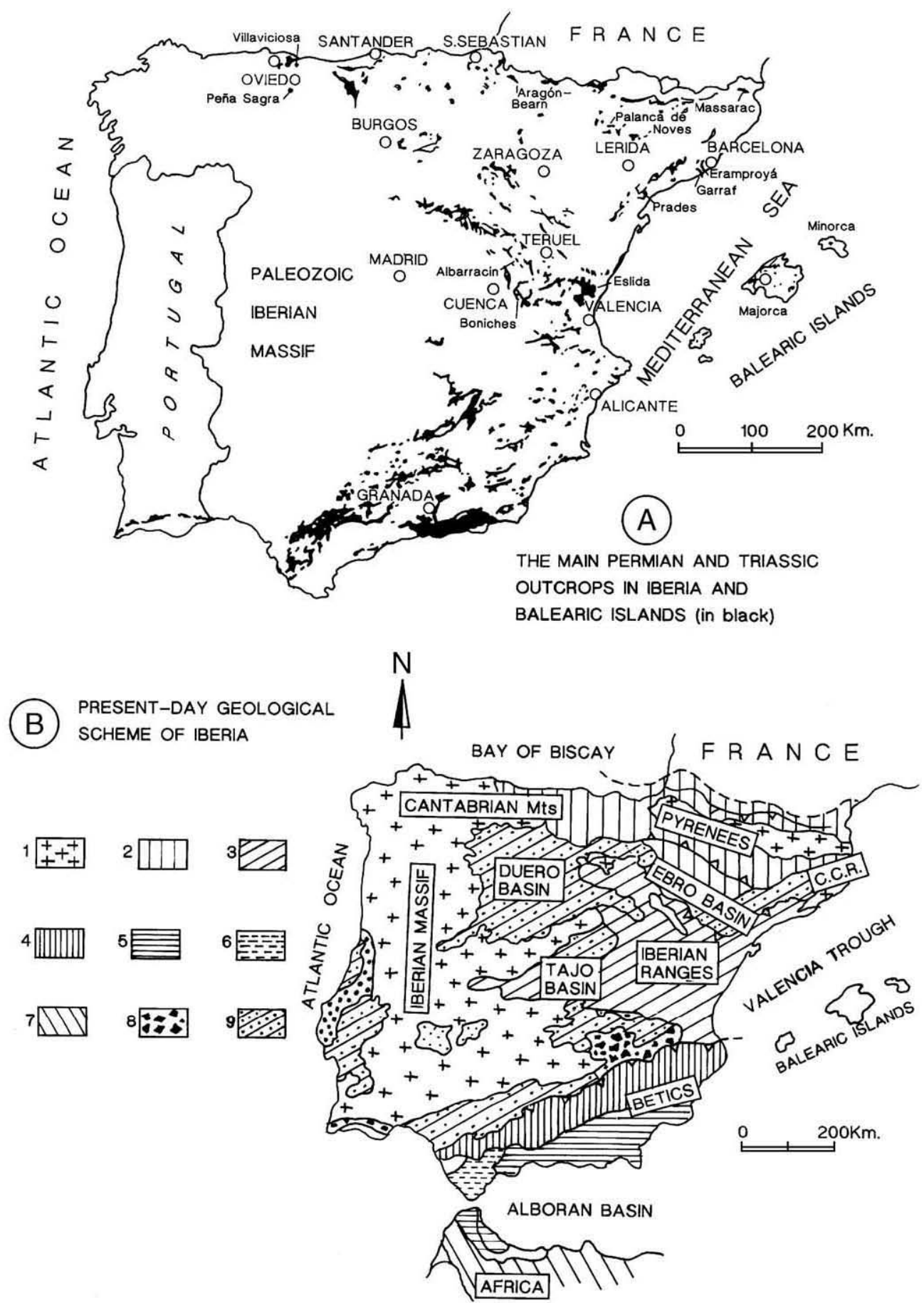

Fig. 1. (A) Location (in black) of the Permian and Triassic outcrops in Iberia and Balearic Islands. (B) Present-day geological scheme of Iberia. 
and sedimentological differences. Tetrapod fauna and sporomorph associations are among the most revealing palaeontological correlation data for continental sediments, but unfortunately not all basins are sufficiently rich in these fossils. Furthermore, the PTB in most continental basins still shows many correlation problems.

The scope of the present report is to contribute to the discussion of the timing and events at the PTB in continental sediments by means of describing the age and the sedimentary and palaeogeographic characteristics of the sediments of the Permian-Triassic transition in the Iberian Plate up to the first invasion of the westward expanding Tethys during the Anisian (Fig. 1A). We discuss the problem represented by the gaps in the sedimentary record for this transition and the changing palaeogeography of this area induced by rapid extensional dynamics. Four main domains (Cantabrian-Pyrenean, Iberian, Catalonian and Betics), or the present-day Alpine ranges (Cantabrian Mountains, Pyrenees, Iberian Ranges, Catalonian Coastal Ranges and Betic Cordillera, respectively) contain Permian and Triassic sediments in the Iberian Plate (Fig. 1B). The Betic Cordillera is out of the scope of this work since they only show a few and incomplete outcrops, and palaeogeographic connections with coeval strata in the northern basins are still uncertain (Simon, 1987). These basins, as most of the Western and Central European basins of the same period of time, were related to multidirectional rift systems refilled with alluvial, marine carbonates and evaporitic sediments that constitute the classic trilogy of the German basin Triassic: Buntsandstein, Muschelkalk and Keuper.

\section{The Upper Permian-Lower Triassic sediments and their age in Spain}

The first appearance of the conodont Hindeodus parvus was proposed as the most precise and widespread datum for defining the PTB in the proposed marine global stratotype section in Meishan, China (Yin et al., 1988, 1996). However, in many other areas, as in Germany (the Buntsandstein) or in the Urals (the top of the Permian), the rocks of this boundary are of continental origin, and thus unsuitable for a worldwide correlation. Many efforts have recently focused on establishing correlations between the PTB in continental basins and the PTB in the marine sediments of Meishan. Although there are still several obstacles, such as the possibility that the first appearance datum of Hindeodus parvus in the Meishan section is asynchronous (Baud, 1996), correlation attempts include the use of the Illawarra magnetic reversal recently proposed by Menning (2001) or the complete study performed in Jameson Land, East Greenland (Twitchett et al., 2001; Stemmerick et al., 2001), showing well-preserved marine fauna and terrestrial palynomorphs in the same area such that biotic crises in the marine and terrestrial realms can be compared in samples from the same section. Moreover, the combined presence in the Jameson Land section of the conodont Hindeodus parvus and a $\delta^{13} \mathrm{C}_{\text {carb }}$ record may allow for correlations between terrestrial strata and the marine Meishan section.

In spite of these efforts, determining the location of the PTB in continental sediments, remains a matter of discussion. The lack of reliable fossil zones in Western Europe, as in Iberia, has largely hampered the biostratigraphical classification of Permian rocks, traditionally dependent on lithostratigraphical considerations. However, in many Permian successions of Western Europe, palynological data has successfully allowed for regional correlations outside the area of the Central Europe Zechstein Basin, where some successions traditionally considered as Late Permian are still of dubious age.

\subsection{Age of the sediments}

In Spain, the youngest Permian sediments belong to the Thuringian, a Western European stratigraphic term approximately equivalent to the upper half part of the Zechstein epoch (Fig. 2). All show different characteristics, although there are several important gaps of deposition in the sedimentary record. The oldest sediments of Triassic age are up to now dated as Anisian. To date, there are no sediments dated as Scythian (Lower Triassic) in Iberia (López-Gómez et al., 2002).

Table 1 provides a summary of the Upper Permian-Lower Triassic units of the main Iberian Plate Permian-Triassic basins examined here. The Late Permian (Thuringian) and Middle Triassic Anisian ages of 


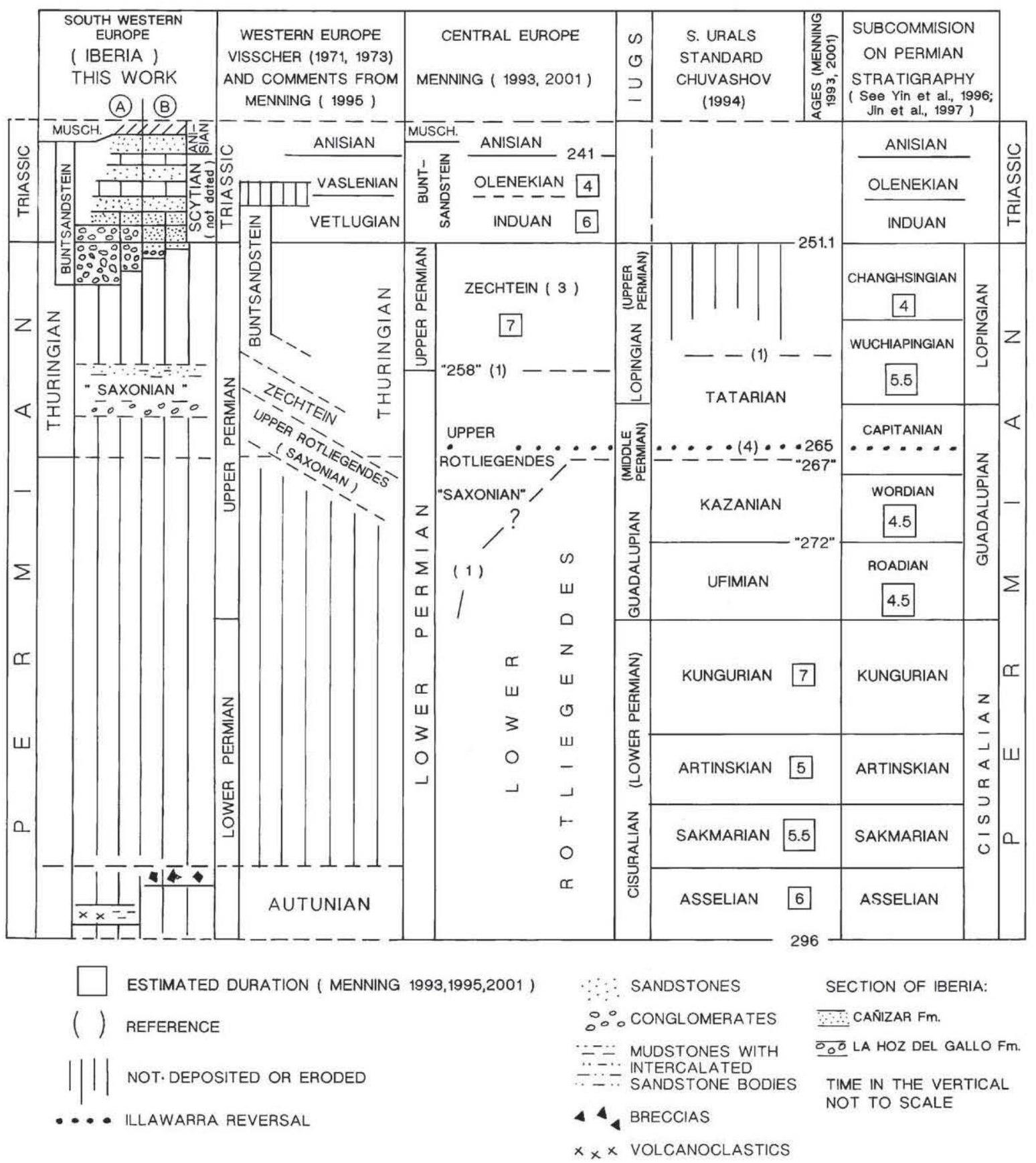

Fig. 2. Permian-Lower Triassic stratigraphic scheme of Theria (this work), Western and Central Europe and S. Urals and essay of their possible units equivalence using time scale calibrations from Menning $(1993,1995,2001)$ and standard stages accepted by the Subcommission on Permian Stratigraphy (SPS) (see Yin et al., 1996) of the IUGS. Permian standard stages from the Asselian to Capitanian are from Jin et al. (1997). The Buntsandstein units in Tberia range from upper Thuringian to Anisian in age, although there being no evidence up to now of the Scythian in this area. In the Tberia section, that represents this work, A refers to the presence of conglomerates from the La Hoz del Gallo Formation (central area of the Tberian Ranges) and B to the absence of this unit, or the presence of only few meters of this unit (SE of the Iberian Ranges). 
Table 1

Synthesis of the stratigraphical units of the Late Permian-Lower Triassic basins of Theria and Balearic Islands

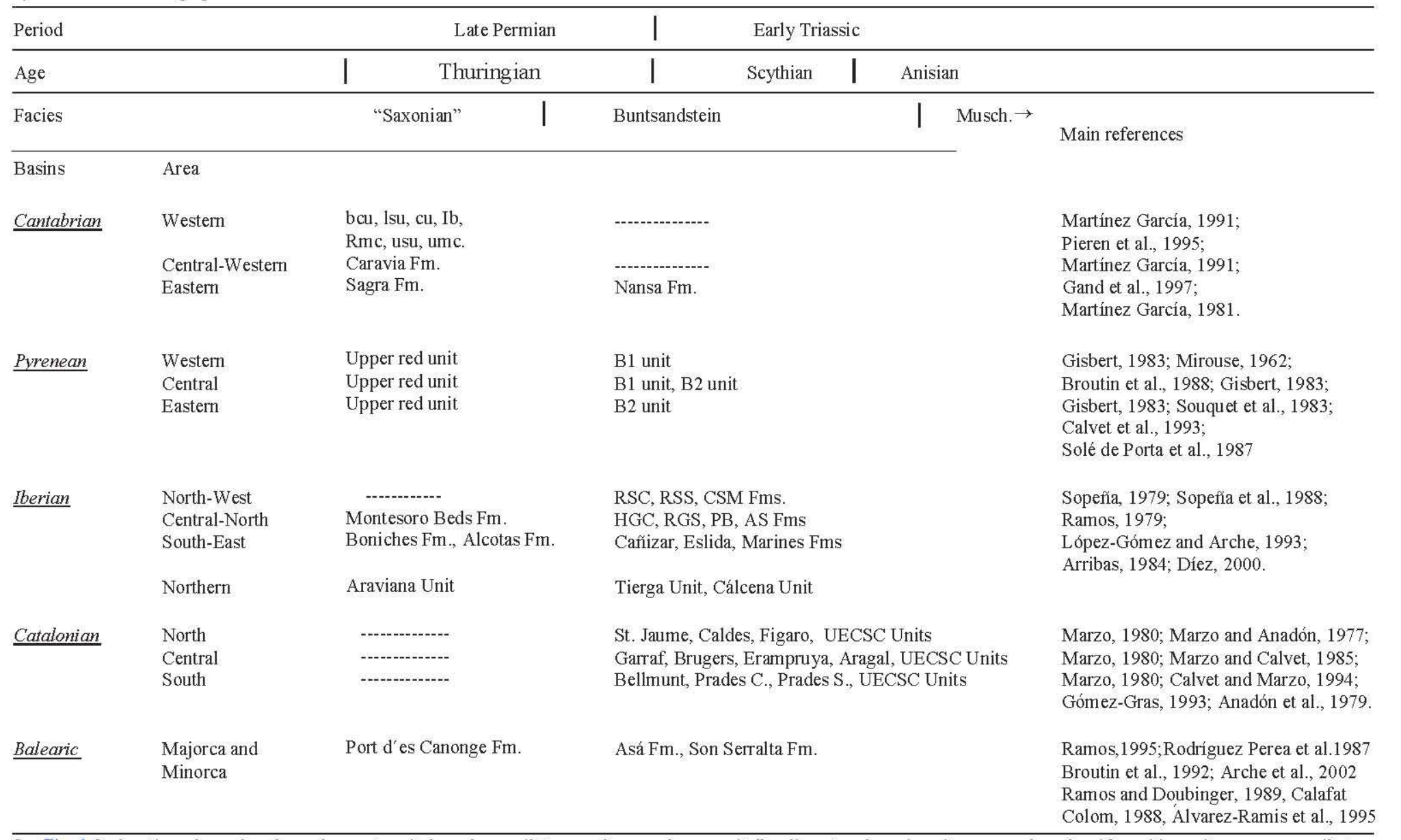

See Fig. 1 for locations. bcu—basal conglomerate unit, lsu—lower siltstone unit, cu—el cayo unit, lb—limestone breccia unit, rmc —red marls with cavities unit, usu—upper siltstone unit, umc - upper marls and clays unit, RSC - Riba de Santiuste Conglomerate, RSS - Riba de Santiuste Sandstone, CMS — Cercadillo Mudstone and Sandstone, HGC - La Hoz del Gallo Conglomerate, RGS-Rillo de Gallo Sandstone, PB-Prado Beds, AS-Arandilla Sandstone. 
the continental sediments in Iberia have been basically inferred from pollen and spore assemblages in the Catalonian (Virgili, 1958; Marzo and Calvet, 1985; Solé de Porta et al., 1987; Calvet and Marzo, 1994) and Iberian Ranges (Boulouard and Viallard, 1971; López-Gómez et al., 1984; López-Gómez, 1985; Doubinger et al., 1990; Sopeña et al., 1995; Gisbert, 1983; Díez, 2000). Upper Palaeozoic sediments (Caravia Formation) in the Central Cantabrian Basin have been identified as Upper Permian (Martínez-García, 1991) using stratigraphical criteria, while strata attributed to the Anisian never have been dated. In the western Pyrenean Basin, both the Late Permian (Thuringian) and Anisian have been located through palynomorph assemblages (Broutin et al., 1988; Calvet et al., 1993). The sedimentary record and age data for the Iberian and Catalonian Ranges are clearly more detailed than those for the Cantabrian and Pyrenean Basins, and are therefore used as the basis for the present study and as a reference for comparisons with other basins. A scheme of the main characteristics of the units representing the Permian-Triassic transition in the Iberian and Catalonian Ranges is shown in Table 2.

The available chronostratigraphic data, the good quality of the outcrops and previous stratigraphical work on the continental sediments of the PTB of the Iberian basin are such that these sections may be correlated with other classic sections of the presentday circum-Mediterranean area, such as those of Cassinis et al. (1992). Fig. 2 shows a stratigraphic scheme of the Lower and Upper Permian units and Lower Triassic of different areas proposed by several authors. Time scale calibration was based on Menning (1995, 2001). This scheme attempts to show the succession of chronostratigraphic units in selected areas rather than correlations among them. Correlations between these selected sections must be regarded as inaccurate, since they are all based on preconceptions as to the relative completeness of the Permian sequence of Western Europe. Only the Tatarian stage of the central part of the Russian platform can be reasonably correlated with the Thuringian based on palynological data (Visscher, 1971). The most detailed and recent zonation by means of palynomorphs of the Permian continental deposits is that of Gorsky et al. (2003) in the classical area of the Russian platform. According to them, the Late Permian Lopingian series are equiva- lent to the upper part of the Tatarian (see Table 1 in Gorsky et al., 2003).

The Tatarian contains two palynomorph zones (Gorsky et al., 2003): Taxodacites permicuus zone (zone 29), at the top, and Vitrieisporites pallidus zone (zone 30 ), at the base. The upper zone, or zone 29 , contains in the Russian platform, among others, Punctatisporites sp., Lycospora sp., Platysaccus papilionis, Lueckisporites virkkiiae, Limitisporites sp., Protohaploxypinus sp. and Protohaploxypinus sevardi, all of them found in the Alcotas Formation, so it is reasonable to attribute a similar age to the Iberian Ranges deposits, that is, upper Tatarian or Late Lopingian (=Thuringian). The lower zone (zone 30) contains, among others, Lycospora sp., Densoisporites nejburgii, Vittatina sp., Falcisporites sp., Lueckisporites virkkiae, all of them found in the Boniches Formation, so a lower Tatarian age is reasonable for this sediments. As the zone 31, also from the above mentioned authors, also contains among others Lueckisporites virkkiae and Vittatina sp., a Middle Permian age (Kazanian, or lower Wordian in the Chinese marine series), cannot be ruled out, but the time interval between the basal Changhsingian and the lower Wordian is about $15 \mathrm{Ma}$ and the Boniches Formation of alluvial fan origin is only about $80 \mathrm{~m}$ thick, these deposits cannot represent this long time span, so we consider that only the zone 30 , or even its upper part, is present in this formation.

The sections selected for this study are summarised form based on recent descriptions of the most complete sections reported in López-Gómez et al. (2002) for Permian and Triassic strata in the Iberian Ranges and Catalonian Ranges of eastern Iberia. At these sites, sections are more complete than in the rest of Iberia and contain abundant palynoflora. The remaining sections comprising this figure are the standard stages accepted by the Subcommission on Permian Stratigraphy (Yin et al., 1996; Jin et al., 1997) and three sections of the classic, representative european areas: Western Europe (Visscher, 1971, 1973), Central Europe (Menning, 1993, 1995) and the S. Urals (Chuvashov, 1994).

The Saxonian term has been abandoned by many authors since it was originally based on two completely different formations in Germany that were traditionally thought to be equivalent (Visscher, 1973). In Iberia, the "Saxonian" term has been traditionally used 
Table 2

Synthesis of the main sedimentary characteristics of the Permian-Triassic transition units in the Iberian and Catalonian Basins

\begin{tabular}{|c|c|c|c|c|c|c|c|c|c|}
\hline \multirow[t]{3}{*}{ Period } & \multirow[t]{3}{*}{ Facies } & \multicolumn{8}{|c|}{ Basins } \\
\hline & & \multicolumn{3}{|c|}{ Iberian } & \multicolumn{5}{|c|}{ Catalonian } \\
\hline & & Unit & Area & Description-Interpretion & References & Unit & Area & Description-Interpretion & References \\
\hline 㤩 & \multirow{2}{*}{ 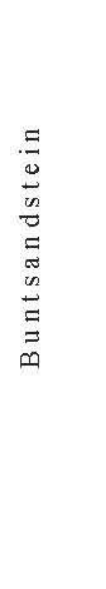 } & $\begin{array}{l}\text { Rillo de } \\
\text { Gallo } \\
\text { or } \\
\text { Caniizar }\end{array}$ & $\begin{array}{l}\text { Central } \\
\text { SE }\end{array}$ & $\begin{array}{l}\text { Medium-grained red } \\
\text { sandstones and intercalated } \\
\text { conglomerates. Longitudinal } \\
\text { and transversal bars } \\
\text { Thickness: } 40-150 \mathrm{~m} \text {. } \\
\text { Fluvial braided systems. }\end{array}$ & $\begin{array}{l}\text { Ramos, 1979; } \\
\text { Ramos et al., 1986; } \\
\text { Pérez-Arlucea and } \\
\text { Sopeña, 1985. } \\
\\
\text { López-Gómez and } \\
\text { Arche,1993; Arche } \\
\text { and López-Gómez, } \\
\text { 1999. }\end{array}$ & Garraf & Garraf & $\begin{array}{l}\text { Medium-grained red } \\
\text { sandstones with } \\
\text { longitudinal and } \\
\text { transversal bars } \\
\text { Thickness: } 40-60 \mathrm{~m} \text {. } \\
\text { Fluvial braided } \\
\text { systems. }\end{array}$ & $\begin{array}{l}\text { Marzo, } 1980 \\
\text { Anadón et al., } \\
\text { 1979; Calvet and } \\
\text { Marzo, } 1994 .\end{array}$ \\
\hline 惡 & & $\begin{array}{l}\text { Hoz del } \\
\text { Gallo. }\end{array}$ & Central & $\begin{array}{l}\text { Quartzite subrounded } \\
\text { conglomerates with planar } \\
\text { cross-stratification. } \\
\text { Thickness: } 10-150 \mathrm{~m} \text {. } \\
\text { Alluvial fans progradation } \\
\text { into transversal braided } \\
\text { plains. }\end{array}$ & \begin{tabular}{|l|} 
Ramos,1979; \\
Ramos and \\
Sopeña, 1983; \\
Ramos et al., 1986.
\end{tabular} & Erampruyá & Garraf & $\begin{array}{l}\text { Subrounded quartzite } \\
\text { conglomerates. Planar } \\
\text { cross-stratification. } \\
\text { Thickness: } 10-40 \mathrm{~m} \\
\text { Braided rivers in } \\
\text { proximal alluvial fan } \\
\text { complex. }\end{array}$ & $\begin{array}{l}\text { Marzo, 1980; } \\
\text { Anadón et al., } \\
\text { 1979; Marzo and } \\
\text { Calvet, } 1985 .\end{array}$ \\
\hline
\end{tabular}

See Fig. 1 for locations. 
to denote a facies of red beds stratigraphically located between the two unconformities that separate these sediments from the Buntsandstein and the Autunian (Fig. 3A), i.e., the Alcotas and Boniches Fms., with typical Thuringian palynomorph associations but with some Autunian palynomorphs still included in the associations found near the base of these sediments (Doubinger et al., 1990). In the same way, the term Buntsandstein is used here as a facies and does not represent the time equivalent of the Buntsandstein of the Lower Triassic classic Germanic-type sediments. Autunian sediments fall out of the scope of this work.

In the Iberian Ranges, the "Saxonian" facies (Fig. 2 ) is very well developed. It mainly consists of conglomerates in the lower part, the Boniches Formation (López-Gómez and Arche, 1997) (Fig. 3B), and siltstones and sandstones, the Alcotas Formation (Arche and López-Gómez, 1999), or its northwestern lateral equivalent, the Montesoro Beds (Ramos, 1979) in the upper part (Fig. 3C). The age of both formations is Thuringian, well determined by means of pollen and spore assemblages (Doubinger et al., 1990; Sopeña et al., 1995), although the presence of Vittatina and Potoniesporites (Autunian forms) in the Boniches Formation assemblages indicates that the latter formation would correspond to the lower part of the Thuringian (Doubinger et al., 1990).

A clear unconformity, traditionally related to the Palatinian orogenic phase of Central Europe, separates the "Saxonian" facies sediments from those represented by the Buntsandstein facies sediments (Fig. 3D). This latter facies is represented from bottom to top by quartzitic conglomerates, the La Hoz del Gallo Formation (Ramos, 1979) (Fig. 3E) only in the central areas of the Iberian Ranges, red sandstones represented by the Rillo de Gallo Formation (Ramos, 1979) or its time equivalent, the Cañizar Formation (Fig. 3F), from Ramos (1979) and López-Gómez (1985) respectively, red siltstones and sandstones, the Eslida Formation or its time equivalent Cálcena Formation, from Arche and López-Gómez (1999) and Arribas (1984), respectively (Fig. 3G), only in the eastern area of the Iberian Ranges, and clays, marls and mudstones, or Röt (upper Buntsandstein) facies, the Marines Formation, from López-Gómez and Arche (1992) (Fig. 3H). Herein, we only focus on the sediments related to the PTB, thus will only deal with the $\mathrm{La} \mathrm{Hoz} \mathrm{del} \mathrm{Gallo} \mathrm{and} \mathrm{Cañizar} \mathrm{Formations}$
(Buntsandstein Facies) (Fig. 2). The age of the La Hoz del Gallo Formation is Thuringian (Ramos and Doubinger, 1979) and that of the upper Cañizar Formation is Anisian (Doubinger et al., 1990). The upper transition of the $\mathrm{La} \mathrm{Hoz}$ del Gallo Formation to the Cañizar Formation is gradual, although the first unit changes its thickness laterally as its lower part was not deposited eastward of the Iberian Basin (see A and B in the stratigraphic scheme for Spain shown in Fig. 2).

\section{The Permian-Triassic boundary in Spain}

In Spain, as in most of Europe, the lack of a complete biostratigraphically based classification for the PTB has prompted the need for a lithostratigraphical approach (Virgili et al., 1983; Sopeña et al., 1983, 1988; Virgili, 1987; López-Gómez et al., 2002). Further, only the Permian and Triassic sedimentary successions of the Iberian Ranges have yielded palynological information on the sedimentary units of this time interval.

The sedimentary record clearly differs from the Permian to the Triassic in the Iberian Plate basins (Fig. 1). In the Cantabrian Mountains and Pyrenees, the scarcity of Upper Permian-Lower Triassic sediments is an important characteristic (Martínez-García, 1991, 1999; Gisbert, 1984; Pieren et al., 1995) (Fig. 4). Only the Central Pyrenees contains a section with two palynological associations indicating Thuringian and Anisian ages for the lower and upper portions of the Buntsandstein facies, respectively (Broutin et al., 1988) (Fig. 4). The Iberian Ranges, Catalan Ranges and Balearic Islands show a similar but more complete succession. These basins have Thuringian palynological assemblages in the lowest Buntsandstein sediments (Boulouard and Viallard, 1971; Ramos and Doubinger, 1979; Sopeña, 1979; Ramos and Sopeña, 1983; PérezArlucea and Sopeña, 1985; Doubinger et al., 1990; Sopeña et al., 1995 for the Iberian Ranges, Marzo and Anadón, 1977; Anadón et al., 1979; Marzo and Calvet, 1985; Solé de Porta et al., 1987 for the Catalonian Ranges, and Bourrouilh, 1973; Ramos and Doubinger, 1989; Calafat Colom, 1988; Broutin et al., 1992; Gómez-Gras, 1993; Álvarez-Ramis et al., 1995 for the Balearic Islands).

The lower part of the Buntsandstein facies, or the La Hoz del Gallo Formation consists of a series of 
A

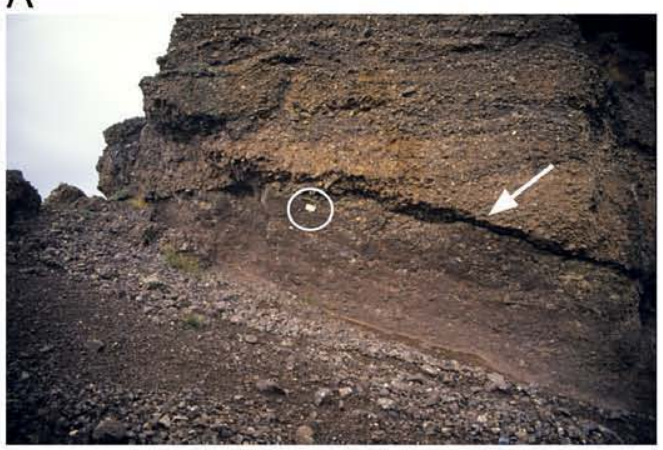

C

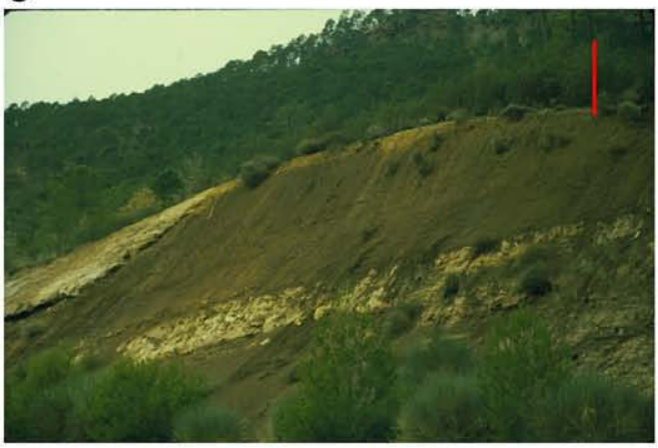

E

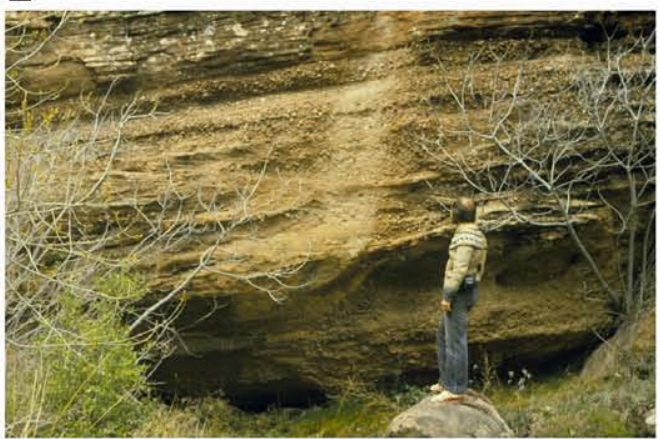

G

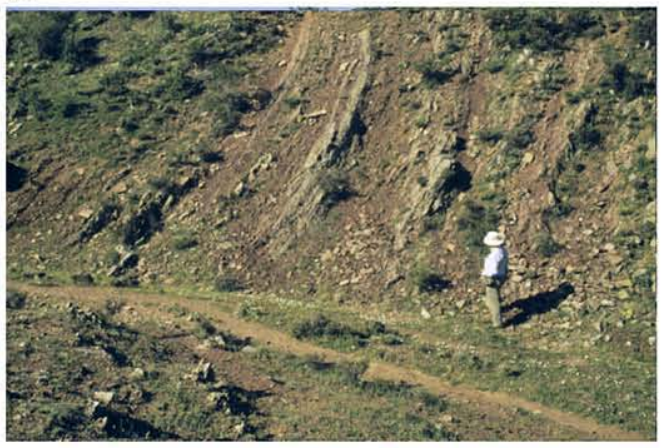

B

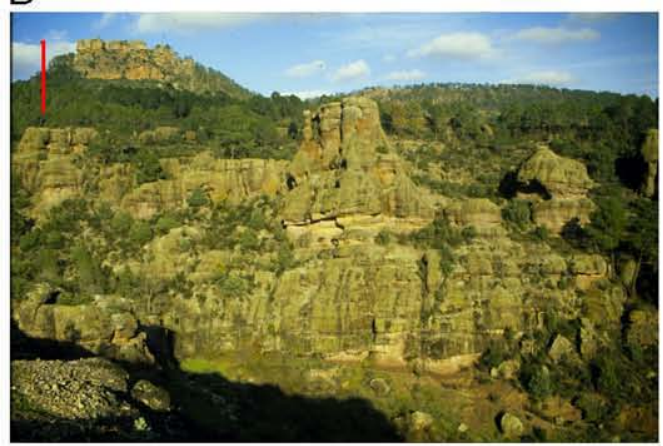

D

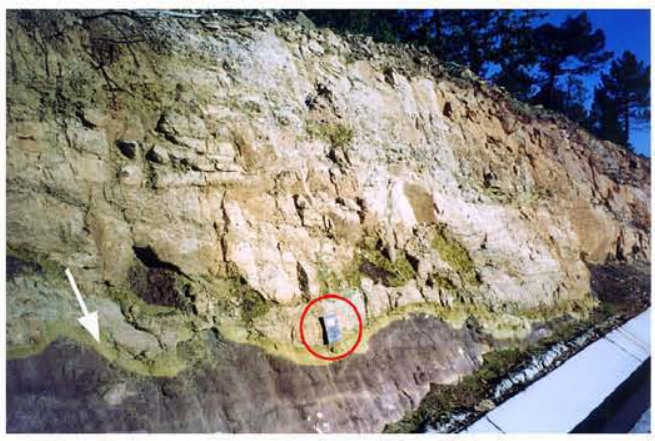

F

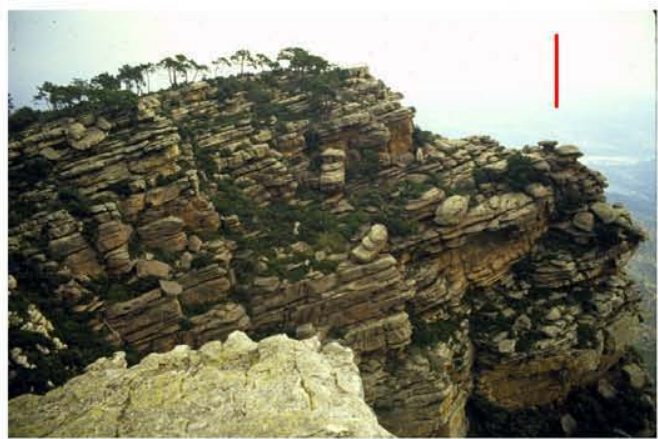

$\mathrm{H}$

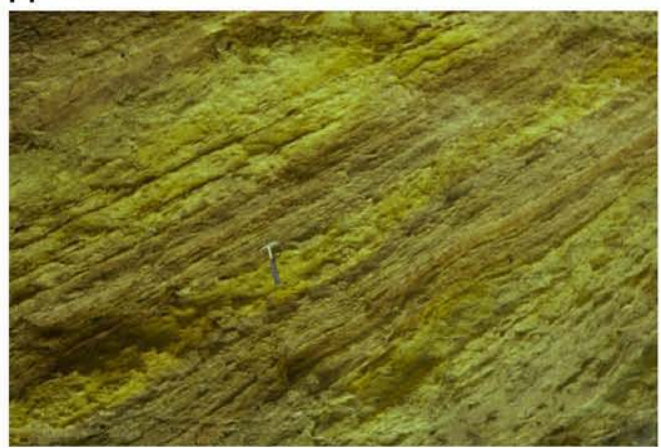


fining-upward sequences of rounded conglomerates deposited by braided fluvial systems, ranging from 50 to $150 \mathrm{~m}$ in thickness (Ramos, 1979). The La Hoz del Gallo Formation only crops out in the central area of the Iberian Ranges.

The middle Buntsandstein facies sediments of Iberia mainly consist of red sandstones and are represented by the Cañizar or Rillo Formations in the Iberian Ranges or its equivalent Eramprunyá Formation (Marzo, 1980) and Asá Formation (Ramos, 1995) in the Catalonian Ranges and Balearic Islands, respectively (Fig. 4). From a sedimentological perspective, these units are interpreted as braided fluvial systems. In the Cañizar Formation, López-Gómez and Arche (1993) mapped 6th-order surfaces and interpreted them to be the main bounding surfaces for the entire basin, representing regional erosion surfaces resulting from the reorganization of fluvial depositional systems following pulses of basin-margin faulting and gentle regional tectonic tilting. Each sandstone sheet separated by main bounding surfaces could therefore be defined as an alloformation separated by erosion surfaces. These authors also considered that the time of erosion represented by these latter surfaces was probably much longer than the time represented by the sedimentation of the alloformations, thus the Cañizar Formation, or time equivalent units in neighbouring basins, was deposited over a very long time interval, and although we know that the upper part is Anisian in age by means of a palynological assemblage described by Doubinger et al. (1990), we cannot preclude the age of the lower part. More recently, Díez et al. (1996) and Díez (2000) also described a palaeoflora of Anisian age in the Buntsandstein facies of the Northern or Aragonese branch of the Iberian Ranges.

For the general section of Iberia (Fig. 2), we have chosen what is considered the two more complete representative sections for the $\mathrm{PTB}$, both from the Iberian Ranges, from its central or AlbarracínBoniches area (A) and southeast or Eslida (B) area.
Fig. 4 shows these two (A and B) representative sections of the "Saxonian"-Buntsandstein facies of the Iberian Ranges together with the equivalent representative sections from the rest of the main PermianTriassic basins of Spain.

If the age of the lower part of the $\mathrm{La} \mathrm{Hoz} \mathrm{del} \mathrm{Gallo}$ Formation is Thuringian and the age of the upper part of the Cañizar Formation. is Anisian (Middle Triassic), the PTB in the Iberian Ranges must be located somewhere within these units or corresponds to a gap in the sedimentary record inside these units. Alternative A represents the lowermost location for the and assumes that the palaeogeographical and palaeoclimatological changes inside the Hoz del Gallo Formation indicated by the presence of dreikanter (or ventifacts), total absence of macro- and microflora and change in fluvial style are due to the PTB crisis. In this alternative, the PTB in Iberia could thus be represented in the lower part of the Buntsandstein facies, probably only a few meters above the unconformity separating the "Saxonian" and Buntsandstein facies sediments, or its probable European equivalent, the Palatinian unconformity. Similar hypotheses were proposed by Geiger and Hopping (1968) and Visscher (1971) for the North Sea and Ireland, respectively. Alternative B represents, on the contrary, the uppermost possible location for the PTB somewhere inside the lower part of the Cañizar Formation. This latter case would assume that the sudden change in fluvial style at the base of the Cañizar Formation was caused by the die off the flora in the aftermath of the western Siberia basaltic eruptions. In any case, both alternatives represent an interval no more than $10-30 \mathrm{~m}$ of sediments which is a very short absolute time interval for continental sediments. Only very detailed palaeomagnetic and geochemical studies could give a more precise location for the PTB in this area.

Fig. 4 tries to correlate this boundary with other Permian-Triassic basins of Iberia. The upper member of the La Hoz del Gallo Formation can be correlated

\footnotetext{
Fig. 3. Permian-Lower Triassic units of Central-SE Tberian Ranges. Autunian: A-Tabarreña Formation The arrow is indicating the unconformity between the Autunian and "Saxonian" facies sediments (notebook for scale is $22 \mathrm{~cm}$ ). "Saxonian facies": B-Boniches Formation in the center of the picture (bar for scale in the upper left side is $19 \mathrm{~m}$ ) and C-Alcotas Formation (bar for scale in the upper right side is $3.5 \mathrm{~m}$ ). Buntsandstein facies: D - Unconformity (traditionally related to the Palatinian phase of Central Europe) separating Buntsandstein (above) and "Saxonian facies" (notebook for scale is $22 \mathrm{~cm}$ ), E-La Hoz del Gallo Formation (lower Buntsandstein unit) in Boniches area, F-Cañizar Formation (bar scale is $21 \mathrm{~m}$ ), G-Eslida Formation, H-Marines Formation (or Röt facies) (hammer for scale is in the center of the picture).
} 


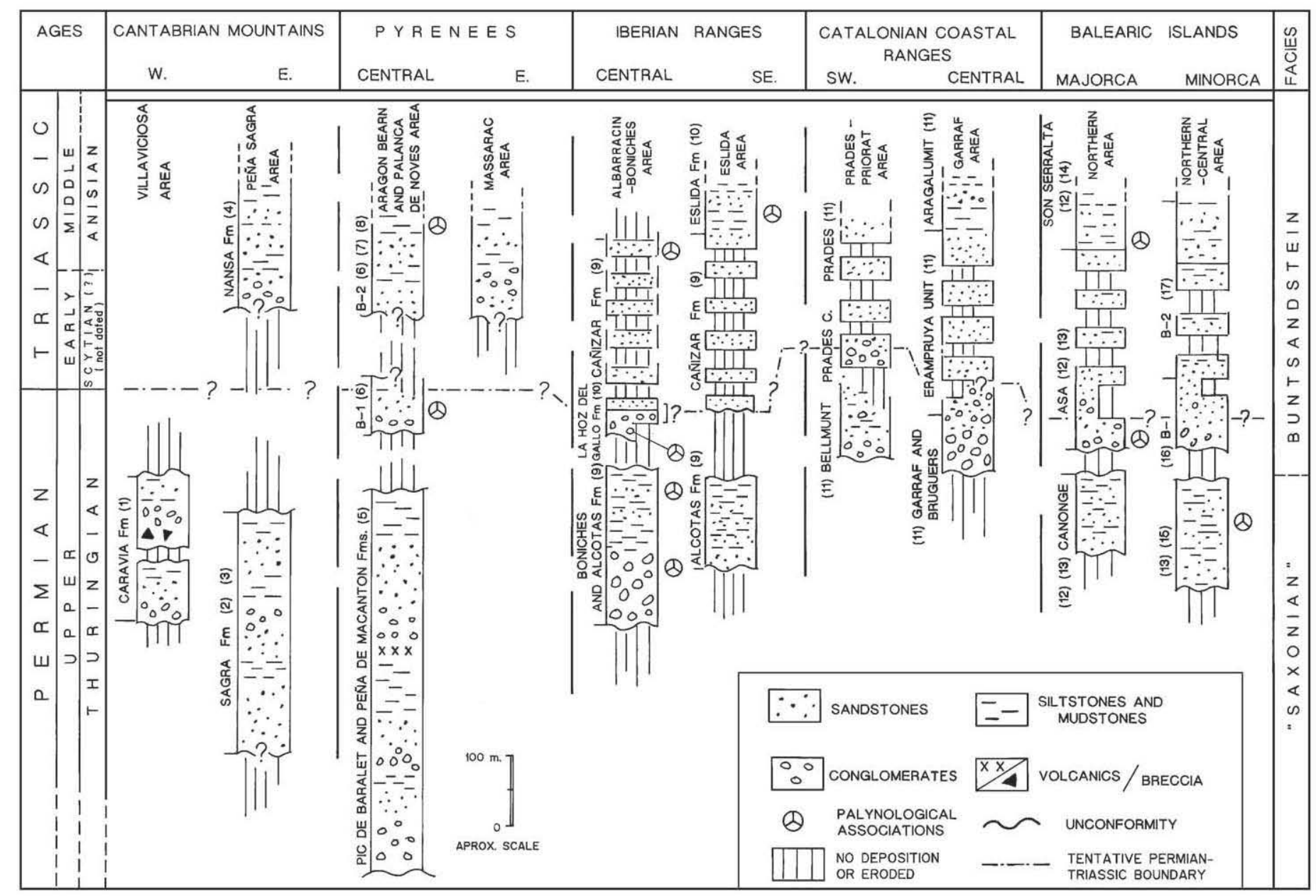

Fig. 4. Representative sections and units of the Permian-Triassic basins of Tberia. 1-Martínez-García (1991), 2-Martínez García (1981), 3-Gand et al. (1997), 4-Maas (1974), 5-Mirouse (1962), 6- Lucas and Gisbert (1995), 7-Gisbert (1983), 8-Gisbert et al. (1985) and Broutin et al. (1988), 9-López-Gómez and Arche (1993), 10-Ramos (1979), 11-Marzo (1980), 12-Ramos (1995), 13 - Ramos and Doubinger (1989), 14-Rodríguez-Perea et al. (1987), 15-Rosell et al. (1988), 16-Bourrouilh (1973), 17-Llompart et al. (1987). See Fig. 1 for locations. 
with the upper part of the Prades Conglomerate Unit in the Catalan Ranges and the conglomerates at the base of the Asá Formation in Majorca and the B-1 conglomerates in Minorca in the Balearic Islands (Arche et al., 2004) (Fig. 4).

\section{Palaeogeography}

The Late Permian-Lower Triassic configuration of Pangea is still a major unresolved geodynamic question. Many of the continental collisions, which began in the Carboniferous, reached maturity in the Early Permian, a time in which Pangea was crossed by large mountain ranges. This supercontinent showed signs of inherent instability during the Late Permian after a period of consolidation in Early Permian times (Ziegler, 1982). The Late Permian, however, saw a clear decline in these ranges and many inland basins accumulated huge piles of sediments of continental origin following the reactivation of fracture systems. The Tethys region is certainly on of the most complex regions in Pangea (Scotese and Lanford, 1995) and there is no consensus regarding the number, extent, and configuration of the different crustal blocks that crossed the Tethys at the end of the Palaeozoic (Nie et al., 1990). Despite these problems, several interesting recent Late Permian palaeogeographic reconstructions including the Iberian Plate have appeared in the literature (see Ziegler, 1988, 1990, 1993; Ziegler and Stampfli, 2001; Stampfli and Borel, 2002; Stampfli et al., 2001; Ford and Golonka, 2003; Ronov et al., 1984, among others). These reconstructions are mainly comprised of regionalor global-scale maps based on palaeogeographical summaries.

\subsection{Iberian Plate}

The Iberian Plate was part of the large Hercynian foldbelt that formed at the end of the Carboniferous after the continent-continent collision of Laurasia and Africa (Dewey and Burke, 1973). The evolution of this plate during the latest Carboniferous to Late Triassic times can be divided into three successive periods, each with different tectonic, magnetic and sedimentological characteristics: the Latest Carboniferous-Early Permian, the Late Permian and the
Latest Permian-Late Triassic. This evolution was closely linked to the development of the western Tethys area during these periods of tectonic instability due to substantial plate reorganization (Beauchamp, 1997), clearly related to the replacement of the Palaeotethys by the Neotethys. The latter has a complex history of cannibalism of different generations of back-arcs, as pointed out by Stampfli and Borel (2002), subducting increasingly older and mechanically stronger oceanic lithospheres.

During Latest Permian-Earliest Triassic times, the Iberian Plate was located north of the equator and south of the tropic (Ziegler and Stampfli, 2001; Beauchamp and Baud, 2002) acting as a main doorway for the definitive westward propagation of the Neotethys reaching the plate during the Anisian. The equatorial seaway between the Palaeotethys and western oceans had been previously eliminated due to continued closure between the gondwanan and laurasian elements of Pangea (Ford and Golonka, 2003). As most of Central and Western Europe during the Permian-Triassic transition, Iberia was also affected by a period of regional regression of the Arctic Sea and the inception of a complex, multidirectional rift system that transected the Variscan fold belt (Ziegler, 1990; Doré, 1991). The evolution of this rift system was related to the initial break-up of Pangea and the southward propagation of the Norwegian-Greenland sea rift and development of the Tethys rift systems. As the result of this widespread extensional tectonics, the CantabrianPyrenean, Catalonian and Iberian basins were created and began their development during the Thuringian (Arche and López-Gómez, 1996). The opening and evolution of these basins was not synchronous. The Iberian trough was the first to open during the Late Permian, followed by the Catalonian and Cantabrian Pyrenean basins during the Early Triassic. The Betic and Western Lusitanian basins appeared later, perhaps during the Middle to Late Triassic. Fig. 5 shows a scheme of the palaeogeographical reconstruction of Iberia and its relationship with the western Tethys area, indicating the main zones of sedimentation, elevated areas and those covered by the sea. The general interpretation of the western Tethys in this figure is based on Ziegler and Stampfli (2001), Ziegler (1988), Stampfli and Borel (2002) and Ford and Golonka (2003). 


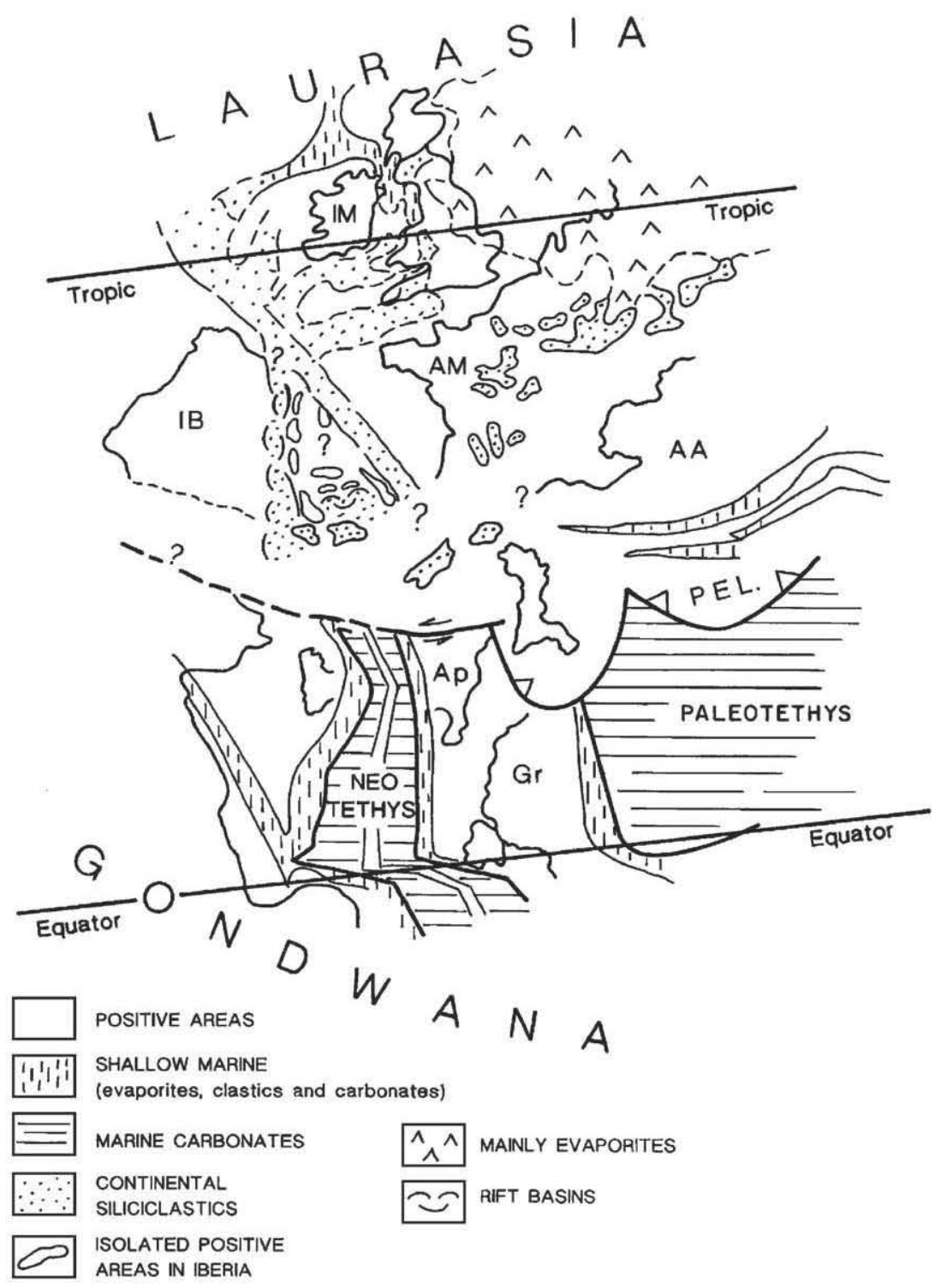

Fig. 5. Palaeogeographical reconstruction essay of Iberia and its location in western Tethys for the Late Permian-Lower Triassic. The Iberian Plate data is obtained from this work, the rest of the information is based on Ziegler (1988) and Ziegler and Stampfli (2001).

Some of the basins of Iberia were the result of reactivation of ancient Hercynian faults (Arthaud and Matte, 1977; Álvaro et al., 1979; Ziegler, 1988; Arche and López-Gómez, 1996), representing the initial phase of post-Variscan plate reorganization. This initial break-up of Pangea was related to a series of strike-slip faults that dissected the Variscan foldbelt and its associated foreland areas. The devel- opment of the different rift systems in Central and Western Europe was not coeval and did not affect the Iberian Plate. After minor faulting induced by transtensional deformation during Stephanian-Autunian times, Iberia, as well as part of NW Africa, formed a coherent positive area while major grabens that had already started to form during the deposition of the Rotliegendes occupied the area from Poland to 
the Black Sea. The seas of the End Permian advanced westward along the axes of these pre-existing rift systems, while basins in Iberia were filled by thick, red beds sequences of continental origin (Sopeña et al., 1988; Van Wees et al., 1998; Arche and LópezGómez, 1999).

Three main rift systems crossed the Iberian Plate during the time of transition from the Permian to the Triassic: NW-SE, N.NW-S.SE and NE-SW related to the Cantabrian-Pyrenean, Iberian and Catalan basins, respectively (Fig. 5). However, these systems did not originate at the same time. The NW-SE rift system was related to the Pyrenean-Bay of Biscay wrench fault system, probably already associated during Latest Carboniferous times with the propagation of the southern Irish Massif rift troughs. During Late Permian times, and only in a punctate manner during the Autunian, the N.NW-S.SE trend was developed as an associated system arising from the opposite movement of the two major bounded fault systems of the Iberian Plate: Chedabucto-Gibraltar and Pyrenean-Bay of Biscay (Arthaud and Matte, 1977). The latter NESW rift system is the youngest. It commenced development during the Late Permian when troughs were refilled with "Saxonian" facies sediments and underwent clear reactivation during Early Triassic-Anisian times, with thick red beds sequences accumulations of Buntsandstein facies and allowing the first entrance of the Neotethys waters that resulted in extensive accumulations of shallow waters sediments (upper Buntsandstein or Röt facies) plus Muschelkalk facies (Fig. 5). This latter reactivation was intimately related to the rapid southward propagation of the northern EuropeGreenland sea rift across the Hesse-Burgundy corridor that reached the Iberian Plate during Early Triassic times and propagated southwestward until the Middle Triassic (Arche and López-Gómez, 1996). Different isolated small highs arose along the elevated flanks of the main troughs. The distribution of these small blocks are still a matter of debate, although recent detailed isopach maps (López-Gómez et al., 1998 , 2002; Van Wees et al., 1998; Arche et al., 2002; Vargas, 2002) enabled us to reconstruct their location with more accuracy (Fig. 5). This distribution permits us to determine that some traditionally interpreted highs, as the Ebro, Lleida or Montalbán, are represented by small elevated areas, rather than large, isolated areas.
It may be concluded that the general development of the Late Permian-Triassic basins of Iberia followed a similar pattern to those in Europe, although this development was not coeval. Furthermore, facies representing sediments refilling the European rifts systems, "Saxonian" and Buntsandstein and later, Muschelkalk and Keuper, occurred with some degree of thickness variation in different European basins but are of different age, since the main rift systems propagating from the $\mathrm{E}$ and $\mathrm{NE}$ took several millions of years, promoting diachronous facies changes.

\subsection{Late Permian climate in the Iberian Plate}

The Permian represents a period of global palaeoclimate changes, with a continental glaciation, that probably ceased before middle Permian (Jones and Fielding, 2004) and the beginning of the megamonsoon climate type (Parrish, 1992, 1995; Kutzbach and Gallimore, 1989). Climate on a particular continent is controlled by the latitudinal position, size and topography of the continent, yet global climate patterns themselves may also be influenced by the relative distribution of continents, oceans and mountain ranges (Ruddiman and Kutzbach, 1991). Thus, the global climate for any interval must be considered in a general palaeogeographic context.

Estimations of palaeoclimates for the Late Permian have mainly been based on simulations involving highly idealized continental geometries (Hay et al., 1990), atmospheric general circulation and oceanic circulation models (Kutzbach et al., 1990), energy balance climate models (Crowley et al., 1989), models based on analogies with the present-day (Parrish, 1982) or general circulation simulations. Among other variables, these models include patterns of surface temperature, precipitation and evaporation balance and sea-level pressure parameters and have provided data on the role of continental configuration as a climateforcing factor (Barron and Facett, 1995). The different palaeoclimate approaches make a comprehensive analysis of the general Permian model climate difficult, yet several clear and common Late Permian-Early Triassic palaeoclimate characteristics have emerged for Pangea, including marked seasonal temperatures and intense monsoon circulation.

A simple view of the latitudinal location and the topography of the Iberian Plate shown in the different 
global palaeogeographical maps for the Late Permian-PTB times (see for example Ziegler, 1988; Ziegler and Stampfli, 2001; Stampfli and Borel, 2002) clearly allows us to infer a few basic palaeoclimatic characteristics for this western Tethysian area. The Iberian Plate was part of the Central Pangean Mountain Range, made up of the Appalachian-Mauretanide-Variscan orogenic belts that formed as a result of the diachronous collision between Laurasia and Gondwana (Scotese and Lanford, 1995). This mountain belt, extending across the southeastern seaboard of North America and into western Africa (Mauritania) and northernmost South America, was highest during the Early Permian and had already begun to collapse during the Late Permian. During the Late Permian-Early Triassic, the eastern border of the Iberian Plate was located $400-800 \mathrm{~km}$ from the westernmost part of the Tethys (Fig. 5). Heights for the southern Europe Variscan range are estimated at 2000 to $3000 \mathrm{~m}$ (Fluteau et al., 2003). High mountains along the coast would have captured almost all the moisture, and during summer, coastal regions would have been wet (Parrish, 1995). Since the Iberian Plate was located between the equator and the tropic of Cancer in the Late Permian (Ziegler and Stampfli, 2001), its surface could have been affected by wind currents transporting moisture captured by the mountains. These currents were related to westward flow at the equator and later spread in eastward flows along the northern and southern margins of the Tethys at higher latitudes (Kutzbach et al., 1990). Using surface pressure plots of Pangea, Barron and Facett (1995) described how low pressures could frequently reach this area of the megacontinent in both Late Permian winter and summer.

Thus, high precipitation is inferred for this westernmost margin of the Tethys ocean dominated by monsoon and seasonal regimes. However, since the Variscan mountain ranges substantially declined at the end of Palaeozoic, and the Iberian Plate was some hundred kilometers west of the Tethys coast, it is possible that some inland areas of aridity arose on the plate at the end of the Late Permian time, especially in exposed areas at the top of flanks of the rifting areas (Fig. 5). This seasonal regime with semiarid areas and major rainfall events in floodplains decreasing in intensity in the Triassic is supported by the sedimentary characteristics previously described that show the clasts of the upper part of the La Hoz del Gallo Formation in the Iberian Ranges as well as the detailed study on Late Permian and Early Triassic calcretes in the Balearic Islands and Iberian Ranges (Gómez-Gras and Alonso-Zarza, 2003 and Alonso-Zarza et al., 1999, respectively) as well as by a study on the evolution of fluvial styles in the Iberian Ranges (Ramos et al., 1986; Arche and López-Gómez, 1999). According to Walter's (1984) classification and the possible topographical elevation considered above for the Late Permian, Fluteau et al. (2003) inferred a generally warm temperate, humid climate, with dry summers and local subtropical aridity for the Iberian Plate.

\section{Conclusions}

The lack of sediments and palaeontological data is the main hurdle impeding better knowledge of the Permian-Triassic transition in continental environments. However, continental zones during that transition coincide with vast palaeogeographical expanses of the Pangea interior during this period and recent sedimentary studies have shed new light on this enigmatic geological period based on isotopes, vertebrate extinctions or the detection of fungi among others observations. Despite these new data, correlations between separate continental basins are very difficult to make and it is almost impossible to compare the better-established marine information for this time interval with data derived from sediments of a continental origin. This report reviews information related to the Permian-Triassic continental transition for several basins of Spain including the present-day Balearic Islands and completes our present knowledge of this interval for the Western Europe. Its main contributions are:

1. Present-day sediments of the Iberian Ranges, Central Iberia, show the most complete successions of the Permian-Triassic transition in the Iberian Plate. This area can be correlated with outcrops of the eastern Catalonian Ranges and Balearic Islands. The formations of the Permian-Triassic transition analysed so far have been dated by means of palynological associations and are represented by alluvial sediments, mainly those arising 
from fluvial braided system deposits of different style and evolution.

2. Being aware of the implications and limitations of the data obtained from the sedimentary record and palynological associations and based on new sedimentological characteristics we consider that the PTB in the Iberian Ranges could be located in the interval from the contact between the lower and upper conglomerates of the La Hoz del Gallo Formation, tentatively proposed by (Ramos, 1979), to the lowermost part of the Cañizar Formation and in the time-equivalent units in the Catalonian Ranges, Balearic Islands and Pyrenees.

3. The most representative section of the Iberian Plate is compared to units and ages for Western and Central Europe and the southern Urals, as well as to information of absolute ages from the IUGS and Permian Subcommission.

4. The Iberian Plate occupied a subtropical position in the northern hemisphere, forming part of the southeast border of the Central Pangean Mountain Range, $400-800 \mathrm{~km}$ from the westernmost Tethys margin. These palaeogeographical characteristics place the Iberian Plate under a monsoon and seasonal climate regime with some arid inland areas.

\section{Acknowledgements}

This report is a contribution to project BTE200200775 of the Spanish Ministry of Science and Technology. Finn Surlyk and reviewers Jean Broutin and John Isbell are acknowledged for improving the manuscript with their critical evaluations. We thank Carlos Sanchez and Modesto Escudero for their help with the illustrations and Ana Burton for the first English revision.

\section{References}

Alonso-Zarza, A., Sopeña, A., Sánchez-Moya, Y., 1999. Contrasting palaeosol development in two different tectonic settings: the upper Buntsandstein of the Western Tberian Ranges, Central Spain. Terra Nova 11, 23-29.

Álvarez-Ramis, C., Fernández-Marrón, T., Calafat, F., 1995. Avance sobre la megaflora triásica en facies germánica de Estellenc (sector noroccidental de la Sierra de Tramontana,
Mallorca). Rev. Esp. Paleontol., número Homenaje al Dr Guillermo, 55-58.

Álvaro, M., Capote, R., Vegas, R., 1979. Un modelo de evolución geotectónica para la Cadena Celtibérica. Acta Geol. Hisp. 14, $172-177$.

Anadón, P., Colombo, F., Esteban, M., Marzo, M., Robles, S., Santanach, P., Sugrañes, L., 1979. Evolución tectonoestratigráfica de Los Catalánides. Acta Geol. Hisp. 14, 242-270.

Arche, A., López-Gómez, J., 1996. Origin of the Permian-Triassic Iberian Basin, central-eastern Spain. Tectonophysics 266, 443-464.

Arche, A., López-Gómez, J., 1999. Tectonic and geomorphic controls on the fluvial styles of the Eslida Formation, Middle Triassic, Eastern Spain. Tectonophysics 315, 187-207.

Arche, A., López-Gómez, J., Vargas, H., 2002. Propuesta de correlación entre los sedimentos pérmicos y triásicos de la Cordillera Tbérica Este y de las Islas Baleares. Geogaceta 32, 275-278.

Arche, A., López-Gómez, J., Marzo, M., Vargas, H., 2004. The siliciclastic Permian-Triassic deposits in Central and Northeastern Iberian Peninsula (Tberian, Ebro and Catalan Basins): a proposal for correlation. Geol. Acta 2 (4), 305-320.

Arribas, J., 1984. Sedimentología y diagénesis del Buntsandstein y Muschelkalk de la Rama Aragonesa de la Cordillera Tbérica (Provncias de Soria y Zaragoza). PhD thesis, Universidad Complutense de Madrid, $180 \mathrm{pp}$.

Arthaud, F., Matte, F., 1977. Late Paleozoic strike-slip faulting in Southern Europe and Northern Africa: result of a right lateral shear zone between the Appalachians and the Urals. Geol. Soc. Am. Bull. 88, 1305-1320.

Barron, E.J., Facett, P.J., 1995. The climate of Pangea: a review of climate model simulations of the Permian. In: Scholle, P.A., Peryt, T.M., Ulmer-Scholle, D.S. (Eds.), The Permian of Northern Pangea, Paleogeography, Paleoclimates, Stratigraphy, vol. 1. Springer-Verlag, Berlin, pp. 37-52.

Baud, A., 1996. The Permian-Triassic boundary: recent developments, discussion and proposals. Albertiana 18, 6-9.

Beauchamp, B., 1997. The P-T and other stress-release events in NW Pangea. Pangea (abs.). Gaea Heidelb. 3, 1-68.

Beauchamp, B., Baud, A., 2002. Growth and demise of Permian biogenic chert along northwest Pangea: evidence for end-Permian collapse of thermohaline circulation. Palaeogeogr. Palaeoclimatol. Palaeoecol. 184, 37-63.

Benton, M., Twitchett, R., 2003. How to kill (almost) all life: the end-Permian extinction event. Trends Ecol. Evol. 18, 7, $358-365$.

Boulouard, C., Viallard, P., 1971. Identification du Permien dans la Chaîne Tbérique. Comp. Rend. Acad. Sci. de Paris 272, 2441-2444.

Bourrouilh, R., 1973. Stratigraphie sédimentologie et tectonique de l'île de Minorque et du Nortd-Est de Majorque (Baléares). 2 vol., PhD Thèse, Université de Paris, $822 \mathrm{pp}$.

Broutin, J., Doubinger, J., Gisbert, J., Satta-Passini, S., 1988. Premières datations palynologiques dans le facies Buntsandstein des Pyrénées catalanes espagnoles. Comp. Rend. Acad. Sci. de Paris 306, 163-169.

Broutin, J., Ferrer, J., Gisbert, J., Nmila, A., 1992. Première découverte d'une microflore thuringienne dans le facies saxonien de 
l'île de Minorque (Baléares, Espagne). Comp. Rend. Acad. Sci. de Paris 315, 117-122.

Calafat Colom, F. 1988. Estratigrafía y sedimentología de las litofacies Buntsandstein de Mallorca. PhD thesis, Universitat de Barcelona, 125 pp. Unpublished.

Calvet, F., Marzo, M., 1994. El Triásico de las Cordilleras Costero Catalanas: Estratigrafía, Sedimentología y Análisis Secuencial. Field Guide, III Coloquio de Estratigrafía y Paleogeografía del Pérmico y Triásico de España. Cuenca, Spain, 53 pp.

Calvet, F., Solé de Porta, N., Salvany, J.M., 1993. Cronoestratigrafía (Palinología) del Triásico surpirenaico y del Pirineo VascoCantábrico. Acta Geol Hisp 28, 33-48.

Cassinis, G., Toutin-Morin, N., Virgili, C., 1992. Permian and Triassic events in the continental domains of Mediterranean Europe. In: Sweet, W.C., Zunyi, Y., Dickins, J.M., Hongfu, Y. (Eds.), Permo-Triassic Events in the Eastern Thetys, Stratigraphy, Classification and Relations with Western Tethys World and Regional Geology. Cambridge University Press, Cambridge, pp. $60-67$.

Chuvashov, B.I., 1994. Progress report of Permian stratotypes working group. Permophiles 25, 7-8.

Crowley, T.J., Hyde, W.T., Short, D.A., 1989. Seasonal cycle variations on the supercontinent of Pangea: implications for Early Permian vertebrate extinctions. Geology 17, 457-460.

Dewey, J.F., Burke, K., 1973. Tibetan, Variscan and Precambrian basement reactivation: products of a continental collision. J. Geol. 81, 683-692.

Díez, J.B., 2000. Geología y paleobotánica de la Facies Buntsandstein de la Rama Aragonesa de la Cordillera Ibérica. Implicaciones paleogeográficas en el Peritethys Occidental. $\mathrm{PhD}$ thesis. Universidad de Zaragoza (Spain) and University Paris 6 (France), 424 pp. Unpublished.

Díez, J.B., Grauvogel-Stamm, L., Broutin, J., Ferrer, J., Gisbert, J., Liñán, E., 1996. Première, découverte d'une paléoflore anisienne dans le facies Buntsandstein de la branche aragonaise de la Cordillére Tbérique. Comp. Rend. Acad. Sci. de Paris 323, $341-347$.

Doré, A.G., 1991. The structural foundation and evolution of Mesozoic seaways between Europe and the Artic. Palaeogeogr. Palaeoclimatol. Palaeoecol. 87, 441-492.

Doubinger, J., López-Gómez, J., Arche, A., 1990. Pollen and spores from the Permian and Triassic sediments of the southeastern Iberian Ranges, Cueva de Hierro (Cuenca) to Chelva-Manzanera (Valencia-Teruel) region, Spain. Rev. Palaeobot. Palynol. $66,25-45$.

Erwin, D.H., 1993. The Great Paleozoic Crisis-Life and Death in the Permian. Columbia Univ. Press, New York. 327 pp.

Eshet, Y., Rampino, M.R., Visscher, H., 1995. Fungal event and palynological record of ecological crisis and recovery across the Permian-Triassic boundary. Geology 23, 967-970.

Fluteau, F., Besse, J., Broutin, J., Ramstein, G., 2003. The Late Permian climate. What can be inferred from climate modelling concerning Pangea scenarios and Hercynian range altitude? Palaeogeogr. Palaeoclimatol. Palaeoecol. 167, 39-71.

Ford, D., Golonka, J., 2003. Phanerozoic paleogeography, paleoenvironment and lithofacies maps of the circum-Atlantic margins. Mar. Pet. Geol. 20, 249-285.
Gand, G., Kerp, H., Parsons, C., Martínez-García, E., 1997. Palaeoenvironmental and stratigraphic aspects of animal traces and plant remains in Spanish Permian red beds (Peña Sagra, Cantabrian Mountains, Spain). Geobios 30, 2, 295-318.

Geiger, M.E., Hopping, C.A., 1968. Triassic stratigraphy of the southern North Sea basin. Philos. Trans. R. Soc. Lond., B $254,1-36$

Gisbert, J., 1983. El Pérmico de los Pirineos españoles. In: Martínez García, E. (Ed.), Carbonífero y Pérmico de España. Ministerio de Industria y Energía, Madrid, pp. 405-420.

Gisbert, J., 1984. Les molasses post-hercyniennes dans le Haut Urgell et la Cerdagne occidentale (Pyrenees Catalanes, Espagne). Comp. Rend. Acad. Sci. de Paris 298, 883-888.

Gisbert, J., Martí, J., Gascón, F., 1985. Guía de la excursión Estefaniense. Pérmico y Triásico Inferior del Pirineo Catalán. Institut d'Estudis Illerdencs, pp. 1-79.

Gómez-Gras, D., 1993. El Permotrías de las Baleares y de la vertiente mediterránea de la Cordillera Ibérica y del Maestrat: facies y petrología sedimentaria (Parte II). Bol. Inst. Geol. Min. Esp. 104, 467-515.

Gómez-Gras, D., Alonso-Zarza, A., 2003. Reworked calcretes: their significance in the reconstruction of alluvial sequences (Permian and Triassic, Minorca, Balearic Islands, Spain). Sediment. Geol. $158,299-319$.

Gorsky, V., Gusseva, E., Crasquin-Soleau, S., Broutin, J., 2003. Stratigraphic data of the Middle-Late Permian on Russian platform. Geobios 36, 533-558.

Hallam, A., Wignall, P.B., 1997. Mass Extinctions and Their Aftermath. Oxford University Press, Oxford. $320 \mathrm{pp}$.

Hancox, P.J., Brandt, D., Reimold, W.U., Koeberl, C., Neveling, J., 2002. Permian-Triassic boundary in the northwest Karoo basin: current stratigraphic placement, implications for basin development models, and the search for evidence of impact. In: Koeberl, C., MacLeod, K.G. (Eds.), Catastrophic Events and Mass Extinctions: Impacts and Beyond, Boulder, Colorado, Spec. Pap.-Geol. Soc. Am., vol. 356, pp. 429-444.

Hay, W.W., Barron, E.J., Thompson, S.L., 1990. Results of global atmospheric circulation experiments on an Earth with a meridional pole-to-pole continent. J. Geol. Soc. Lond. 147, 385-392.

Isozaki, Y., 1997. Permo-Triassic boundary superanoxia and stratified superocean: records from lost deep sea. Science 276 , $235-238$.

Jin, Yugan, Wardlaw, B.R., Glenister, B.F., Kotlyar, G.V., 1997. Permian chronostratigraphic subdivisions. Episodes 20 (1), $10-15$.

Jones, A., Fielding, C.R., 2004. Sedimentological record of the late Paleozoic glaciation in Queensland, Australia. Geology 32 (2), $153-156$.

Kozur, H., 1989. The Permian-Triassic boundary in marine and continental sediments. Geol. Palaeontol. 11-12, 1245-1277.

Kozur, H., 1998. Some aspects of the Permian-Triassic boundary (PTB) and of the possible causes for the biotic crisis around this boundary. Palaeogeogr. Palaeoclimatol. Palaeoecol. 143, $227-272$.

Krull, E.S., Retallack, G.J., 2000. $\delta^{13} \mathrm{C}_{\text {org }}$ depth profiles from paleosols across the Permian-Triassic boundary: evidence for methane release. Geol. Soc. Am. Bull. 112, 1459-1472. 
Kutzbach, J.E., Gallimore, R.G., 1989. Pangean climates: megamonsoons of the megacontinent. J. Geophys. Res. 94, 3341-3357.

Kutzbach, J.E., Guetter, P.J., Wasshington, W.N., 1990. Simulated circulation of an idealized ocean from Pangean time. Paleoceanography $5,299-317$.

Llompart, C., Rosell, J., Márquez-Aliaga, A., 1987. El Muschelkalk de la Isla de Menorca. Cuad. Geol. Ibér. 11, 323-335.

López-Gómez, J., 1985. Sedimentología y estratigrafía de los materiales pérmicos y triásicos del sector SE de la Rama Castellana de la Cordillera Ibérica entre Cueva de Hierro y Chelva (provincias de Cuenca y Valencia). Semin. Estratigr., Ser. Monogr. 11, 1-344.

López-Gómez, J., Arche, A., 1992. Paleogeographical significance of the Röt (Anisian, Triassic) facies (Marines Formation) in the Iberian Ranges, Eastern Spain. Palaeogeogr. Palaeoclimatol. Palaeoecol. 103, 347-361.

López-Gómez, J., Arche, A., 1993. Sequence stratigraphy analysis and paleogeographic interpretation of the Buntsandstein and Muschelkalk facies (Permo-Triassic) in the SE Tberian Ranges, eastern Spain. Palaeogeogr. Palaeoclimatol. Palaeoecol. 103, $179-201$.

López-Gómez, J., Arche, A., 1997. The Upper Permian Boniches conglomerates formation: evolution from alluvial fan to fluvial system environments and accompanying tectonic and climatic controls in the southeast Iberian Ranges, central Spain. Sediment. Geol. 114, 267-294.

López-Gómez, J., Arche, A., Doubinger, J., 1984. Las facies Buntsandstein entre Cañete y Talayuelas (prov. de Cuenca): Caractersticas sedimentológicas y asociaciones palinológicas. Rev. Esp. Micropaleontol. 1, 93-112.

López-Gómez, J., Arche, A., Calvet, F., Goy, A., 1998. Epicontinental marine carbonate sediments of the middle and upper Triassic in the westernmost part of the Tethys Sea, Iberian Peninsula. In: Bachmann, G.H., Lerche, I. (Eds.), Epicontinental Triassic, Zentralblatt für Geologie und Paläontologie, vols. 910 , pp. 1033-1084.

López-Gómez, J., Arche, A., Pérez-López, A., 2002. Permian and Triassic. In: Gibbons, W., Moreno, M.T. (Eds.), The Geology of Spain, Geol. Soc., London, pp. 185-212.

Looy, C., Twitchett, R., Dilcher, R., Konijnenburg-Van Cittert, J.H.A., Visscher, H., 2001. Life in the end-Permian dead zone. Proc. Natl. Acad. Sci. Am. 98, 7879-7883.

Lozovsky, V.R., 1998. The Permian-Triassic boundary in the continental series of Eurasia. Palaeogeogr. Palaeoclimatol. Palaeoecol. 143, 273-283.

Lucas, C., Gisbert, J., 1995. Carbonifêre Supérieur et Permien. In: Barnolas, A., Chiron, J.C. (Eds.), Synthèse Géologique et Géophysique des Pyrénées, BRGM, vol. 1, pp. 339-359.

Maas, K., 1974. The geology of Liébana, Cantabrian Mountains, Spain; flysh area. Leidse Geol. Meded. 49, 379-465.

MacLeod, K., Smith, R., Koch, P., Ward, P.D., 2000. Timing of mammal-like reptile extinctions across the Permian-Triassic boundary in South Africa. Geology 28, 227-230.

Martínez García, E., 1981. El Paleozoico de la zona Cantábrica Oriental (Noroeste de España). Trab. Geol. Univ. Oviedo 11, $97-127$.
Martínez-García, E., 1991. Hercynian syn-orogenic and post-orogenic successions in the Cantabrian and the Palentian zones (NW Spain). Comparison with other western European occurrences. G. Geol. 53, 209-228.

Martínez García, E., 1999. Orogénesis y Sedimentación a Finales Del Paleozoico en el NW del Macizo Ibérico (Asturias, Cantábria y Palencia). Libro Homenaje a José Ramírez del Pozo. AGGEP, Madrid, pp. 167-174.

Marzo, M., 1980. El Buntsandstein de los Catalánides: Estratigrafía y procesos de sedimentación. Unpublished $\mathrm{PhD}$ thesis. Universidad de Barcelona 317 pp.

Marzo, M., Anadón, P., 1977. Evolución y caractersticas sedimentológicas de las facies fluviales basales del Buntsandstein de Olesa de Montserrat (provincia de Barcelona). Cuad. Geol. Ther. 4, 211-222.

Marzo, M., Calvet, F., 1985. El Triásico de los Catalánides. II Coloquio Estratigráfico y Paleogeográfico del Pérmico y Triásico de España. Institut d'Estudis Ilerdencs, Lleida. 175 pp.

Menning, M., 1993. A revised Permian polarity time scale. EUG VII Abstr., Strasbourg, April, 4-8, pp. 4-8.

Menning, M., 1995. A numerical time scale for the Permian and Triassic Periods: an integrated time analysis. In: Scholle, P.A., Peryt, T.M., Ulmer-Scholle, D.S. (Eds.), Paleogeography, Paleoclimates, Stratigraphy, vol. 1. Springer-Verlag, Berlin, pp. 77-97.

Menning, M., 2001. A Permian time scale 2000 and correlation of marine and continental sequences using the Illawarra reversal (265 MA). Nat. Brescia. Ann. Mus. Civ. Nat. Brescia. 25, $355-362$.

Mirouse, R., 1962. Recherches géologiques dans la partie occidentale de la zone axiale primaire des Pyrénées. PhD thesis, Université de Toulouse. Unpublished.

Morante, R., 1996. Permian and Early Triassic isotopic records of carbon and strontium in Australia and a scenario of events about the Permian-Triassic boundary. Hist. Biol. 11, $289-310$.

Nie, S., Rowley, D.B., Ziegler, A.M., 1990. Constraints on the location of the Asian microcontinents in Palaeo-Tethys during the Late Palaeozoic. In: McKerrow, W.S., Scotese, C.R. (Eds.), Palaeozoic Palaeogeography and Biogeography, Geol. Soc. Lond. Mem., 12, pp. 397-409.

Parrish, J.T., 1982. Upwelling and petroleum source beds, with reference to the Paleozoic. Am. Assoc. Pet. Geol. Bull. 66, $750-774$.

Parrish, J.T., 1992. Jurassic climate and oceanography of the circum-Pacific region. In: Westermann, G.G. (Ed.), The Jurassic of the Circum-Pacific. Univ. Press, Oxford, pp. 345-379.

Parrish, J.T., 1995. Geologic evidence of Permian climate. In: Scholle, P.A., Peryt, T.M., Ulmer-Scholle, D.S. (Eds.), The Permian of Northern Pangea, Paleogeography, Paleoclimatology, Stratigraphy, vol. 1. Springer Verlag, Berlin, pp. 53-61.

Pérez-Arlucea, M., Sopeña, A., 1985. Estratigrafía del Pérmico y Triásico en el sector central de la Rama Castellana de la Cordillera Tbérica (provincias de Guadalajara y Teruel). Estud. Geol. 41, 207-222.

Pieren, A., Areces, J., Toraño, J., Martínez García, E., 1995. Estratigrafía y estructura de los materiales permotriásicos del 
sector Gijón-La Camocha (Asturias). Cuad. Geol. Tber. 19, 309-336.

Poor, R.J., Clement-Westerhof, J.A., Looy, C.V., Visscher, H., 1997. Aspects of Permian palaeobotany and palynology: XVII. Conifer extinction in Europe at the Permian-Triassic junction: Morphology, ultrastructure and geographic/stratigraphic distribution of Nuskoisporites dulhuntyi (prepollen of Ortiseia, Walchiaceae). Rev. Palaeobot. Palynol. 97, 9-39.

Racki, G., 2003. End-Permian mass extinction: oceanographic consequences of double catastrophic volcanism. Lethaia 36, $171-173$.

Ramos, A., 1979. Estratigrafía y paleogeografía del Pérmico y Triásico al oeste de Molina de Aragón (Província de Guadalajara). Semin. Estratigr., Ser. Monogr. 6, 1-313.

Ramos, A., 1995. Transition from alluvial to coastal deposits (Permian-Triassic) on the Island of Mallorca, western Mediterranean. Geol. Mag. 132, 435-447.

Ramos, A., Doubinger, J., 1979. Découverte d'une microflore thuringienne dans le Buntsandstein de la Cordillère Ibérique (Espagne). Comp. Rend. Acad. Sci. Paris 289, 525-528.

Ramos, A., Doubinger, J., 1989. Premières datations palinologiques dans le faciès Buntsandstein de l'Île de Majorque (Baleares, Espagne). Compte Rendus des seances de l'Academie des Sciences Paris 309 (II), $1089-1094$.

Ramos, A., Sopeña, A., 1983. Gravel bars in low-sinuosity streams (Permian and Triassic, Central Spain). Spec. Publ. Int. Assoc. Sedimentol. 6, 301-312.

Ramos, A., Sopeña, A., Pérez-Arlucea, M., 1986. Evolution of Buntsandstein fluvial sedimentation in the Northwest Iberian Ranges (Central Spain). J. Sediment. Petrol. 56, 862-875.

Renne, P.R., Basu, A.R., 1991. Rapid eruption of the Siberian traps floods basalts at the Permo-Triassic boundary. Science 253, $176-179$

Retallack, G.J., Krull, E.S., 1999. Landscape ecological shift at the Permian-Triassic boundary. Aust. J. Earth Sci. 46, 785-812.

Rodríguez-Perea, A., Ramos-Guerrero, E., Pomar, L., Paniello, X., Obrador, A., Mart, J., 1987. El Triásico de las Baleares. Cuad. Geol. Tber. 11, 295-321.

Ronov, A., Khain, V., Seslavinsky, K., 1984. Atlas of LithologicalPalaeogeography Maps on the World: Late Precambrian and Paleozoic of Continents. USSR Acad. Sci, Leningrad. $70 \mathrm{pp}$.

Rosell, J., Arribas, J., Elízaga, E., Gómez-Gras, D., 1988. Caracterización sedimentológica y petrográfica de la serie roja PermoTriásica de la Isla de Menorca. Bol. Inst. Geol. Min. Esp. 99, $71-82$.

Rubidge, B., 1995. Biostratigraphy of the Beufort Group (Karoo Sequence), South Africa. Geol. Surv. South Africa Biostratigrph. Series 1, 1-43.

Ruddiman, W.F., Kutzbach, J.E., 1991. Plateau uplift and climatic change. Sci. Am. 264, 66-75

Scotese, C.R., Lanford, R.P., 1995. Pangea and the paleogeography of the Permian. In: Scholle, P.A., Peryt, T.M., Ullmer-Scholle, D.S. (Eds.), The Permian of Northern Pangea, Palaeogeogr. Palaeoclimatol. Biogeogr., vol. 1. Springer, Berlin, pp. 3-19.

Simon, O., 1987. On the Triassic of the Betic Cordilleras (Southern Spain). Cuad. Geol. Tbér. 11, 385-402.
Smith, R.M., Ward, P.D., 2001. Pattern of vertebrate extinctions across an event bed at the Permian-Triassic boundary in the Karoo basin of South Africa. Geology 29, 1147-1150.

Solé de Porta, N., Calvet, F., Torrentó, L., 1987. Análisis palinológico del Triásico de los Catalánides (NE de España). Cuad. Geol. Tbér. 11, 237-254.

Sopeña, A., 1979. Estatigrafía del Pérmico y Triásico del NO de la provincia de Guadalajara. Semin. Estratigr., Ser. Monogr. 5, $1-329$.

Sopeña, A., Virgili, C., Arche, A., Hernando, S., Ramos, A., 1983. El Triásico. In: Fontboté, J.M. (Ed.), Libro Homenaje a J.M. Ríos, vol. 2. IGME, Madrid, pp. 47-62.

Sopeña, A., López, J., Arche, A., Pérez-Arlucea, M., Ramos, A., Virgili, C., Hernando, S., 1988. Permian and Triassic rift basins of the Tberian Peninsula. In: Manspeizer, W. (Ed.), TriassicJurassic Rifting, Developments in Geotectonics, vol. 22. Elsevier, pp. $757-786$.

Sopeña, A., Doubinger, J., Ramos, A., Pérez-Arlucea, M., 1995. Palynologie du Permién et du Trias dans le centre de la Péninsule Ibérique. Sci. Geol., Bull. 48, 119-157.

Stampfli, G.M., Borel, G.D., 2002. A plate tectonic model for the Paleozoic and Mesozoic constrained by dynamic plate boundaries and restored synthetic oceanic isochrones. Earth Planet. Sci. Lett. 196, 17-33.

Stampfli, G.M., Borel, G.D., Cavazza, W., Mosar, J., Ziegler, P.A., 2001. Palaeotectonic and palaeogeographic evolution of the western Tethys and Peritethyan domain (IGCP Project 369). Episodes 24, 222-228.

Stemmerick, L., Bendix-Almgreen, S.E., Piasecki, S., 2001. The Permian-Triassic boundary in Central-East Greenland: past and present views. Bull. Geol. Soc. Den. 48, 2, 159-167.

Twitchett, R., 2001. Incompleteness of the Permian-Triassic fossil record: a consequence of productivity decline? Geol. J. 6, $341-353$.

Twitchett, R., Looy, C., Morante, R., Visscher, H., Wignall, P., 2001. Rapid and synchronous collapse of marine and terrestrial ecosystems during the end-Permian biotic crisis. Geology 29 , $351-354$.

Van Wees, J.D., Arche, A., Beijdorff, C., López-Gómez, J., Cloetingh, S., 1998. Temporal and spatial variations in tectonic subsidence in the Tberian Basin (eastern Spain): inferences from automated forward modelling of high-resolution stratigraphy (Permian-Mesozoic). Tectonophysiscs 300, 285-310.

Vargas, H., 2002. Análisis y comparación de la subsidencia entre las cuencas Tbérica y Ebro Central durante el Pérmico y el Triásico y su relación con el relleno sedimentario. $\mathrm{PhD}$ thesis. Universidad Complutense, Madrid, $310 \mathrm{pp}$.

Virgili, C., 1958. El Triásico de los Catalánides. Bol. Inst. Geol. Min. Esp., 1-856.

Vurgili, C., 1987. Problemática del Tras y Pérmico Superior del Bloque Ibérico. Cuad. Geol. Tbér. 11, 39-52.

Virgili, C., Sopeña, A., Ramos, A., Hernándo, S., 1983. El relleno posthercínico y la sedimentación mesozoica. In: Comba, J. (Ed.), Geologa de España, vol. 2. IGME, Madrid, pp. 25-36.

Visscher, H., 1971. The Permian and Triassic of the Kingscourt outlier, Ireland. A palynological investigation related to regional 
stratigraphical problems in the Permian and Triassic of western Europe. Spec. Pap.-Geol. Surv. Irel. 1, 1-114.

Visscher, H., 1973. The Upper Permian of Western Europe. A palynological approach to chronostratigraphy. Mem.-Can. Soc. Pet. Geol. 2, 200-219.

Visscher, H., Brinkhuis, H., Dilcher, D.L., Elsik, W.C., Eshet, Y., Looy, C.V., Rampino, M.R., Traverse, A., 1996. The terminal Paleozoic fungal event: evidence of terrestrial ecosystem destabilization and collapse. Proc. Natl. Acad. Sci. Am. 93, 2155-2158.

Walter, H., 1984. Vegetation of the Earth and Ecological Systems of the Geobiosphere. Springer, Berlin.

Wignall, P.B., Hallam, A., 1992. Anoxia as cause of the Permian/ Triassic extinction: facies evidence from northern Italy and the western United States. Palaeogeogr. Palaeoclimatol. Palaeoecol. 93, $21-46$.

Yin, H., Tong, J., 1998. Multidisciplinary high-resolution correlation of the Permian-Triassic boundary. Palaeogeogr. Palaeoclimatol. Palaeoecol. 143, 199-212.

Yin, H., Yang, F., Zhang, K., Yang, W., 1988. A proposal to the biostratigraphic criterion on Permian/Triassic boundary. Mem. Soc. Geol. Ital. 34, 329-344.
Yin, H., Sweet, W.C., Glenister, B.F., Kotlyar, G., Kozur, H., Newell, N.D., Sheng, J., Yang, Z., Zakharov, Y.D., 1996. Recommendation of the Meishan section as global stratotype section and point for basal boundary of Triassic system. Newsl. Stratigr. 34, $81-108$.

Ziegler, P.A., 1982. Geological Atlas of Western and Central Europe. Elsevier Sci. Publ, Amsterdam. 130 pp.

Ziegler, P.A., 1988. Post-Hercynian plate reorganization in the Tethys and Artic-North Atlantic domains. In: Manspeizer, W. (Ed.), Triassic-Jurassic Rifting, Developments in Geotectonics, vol. 22. Elsevier, Amsterdam, pp. 711-755.

Ziegler, P.A., 1990. Geological atlas of Western and Central Europe. 2nd ed. Shell Inter. Petroleum Mij. B.V. and Geol. Soc. London. $239 \mathrm{pp}$.

Ziegler, P.A., 1993. Plate-moving mechanism: their relative importance. J. Geol. Soc. Lond. 150, 927-940.

Ziegler, P.A., Stampfli, G.M., 2001. Late Palaeozoic-Early Mesozoic plate boundary reorganization: collapse of the Variscan orogen and opening of Neotethys. Ann. Mus. Sci. Nat. Brescia $25,17-34$. 